\title{
Inside co-production: ruling, resistance, and practice
}

Mark Bevir (University of California, Berkeley), Catherine Needham (University of Birmingham) and Justin Waring (University of Nottingham)

It might be argued that a narrative of co-production has come to re-define contemporary social and public policy. Elinor Ostrom's pioneering work on co-production, that started in the 1970s and was awards the Nobel prize for economics in 2009, offers a way to bridge the gap between the market and the state through involving citizens in the production of common goods (Ostrom et al. 1978; Ostrom 2015). This 'disarmingly simple' idea (Alford 2014) is now engrained within contemporary policymaking and public service delivery (Ansell and Gash 2008), symbolising a more humane and inclusive alternative to New Pubic Management (Newman 2005) and cornerstone to New Public Governance (Osborne et al. 2016).

Yet, the zeitgeist of co-production stretches far beyond social and public policy. It can be found, for example, in the worlds of 'Mode-II' research (Gibbons. 1994); of product development and market testing (Vargo and Lusch 2008); in similar ways, it is found in the co-design of local public services (Crompton et al. 2018); and in the co-formulation of care services (Bate and Robert 2006). For advocates of co-production, the basic assumption is that the users and producers of a given phenomenon (knowledge, policy, services) can work together to co-design, co-create or co-produce the desired outcome. With specific reference to public services, for example, Osborne et al. (2016) define coproduction as "the voluntary or involuntary involvement of public service users in any of the design, management, delivery and/or evaluation of public services" (p.640). As further suggested by Needham (2008: 221) co-production "signals a shift away from defining public services solely in terms of the productive activities of the state".

More than this, however, the narrative of coproduction implies certain beliefs about the deficiencies in unilateral or siloed working to address complex issues; about stakeholders being separated by institutionalised social, cultural or political boundaries; and about persistent power and status inequalities between stakeholders. For most advocates, co-production is more than a method or tool of better decision-making, rather it reflects a political agenda to rebalance inequalities and promote democracy.

The contemporary narrative of co-production, as experienced across these different fields of human activity, has emerged at the confluence of at least three trends, each with particular antecedents and agenda. The first might be regarded as a type of social movement concerned with service-user emancipation that dates back to the 1960s. This emerged, in many instances, as a response to the perceived paternalism and oppression of welfare services, especially the medicalisation of services for people with mental health problems, and those with physical and learning disabilities (Williamson 2008). The challenge presented by this movement was for service users to have a more meaningful and direct influence on the decisions related to the services their receive, but more than this, was the radical goal of challenging dominant interests and emancipating marginalised groups. These ideas have come to re-shape the philosophies and practices of many welfare and social care professions and is now seen, for example, in the Patient-Public Involvement agenda (Brett et al. 2014; Mead and Bower 2000). Although not necessarily framed in terms of coproduction, the political challenge presented to post war welfare services has contributed to the idea that service users should play a more full and meaningful role in determining and planning the services they receive; even if this can 
also be aligned with a more market approach to consumer welfare provision (Department of Health 2012).

The second antecedent to the current coproduction narrative is found in the field of political philosophy and theory. This is arguably rooted in the social theory of Jurgen Habermas (1984) and has found expression in the concept of deliberative democracy (Dryzek 2002). The basic premise is that established political systems are in some sense in deficit, and in turn lacking in accountability and legitimacy, because they tend to replace participatory spaces for citizen deliberation with forms of representative democracy. What is needed, therefore, are more spaces for communicative acts of emancipation, in which citizens articulate, deliberate and validate arguments to reach some shared normative rationality. Through this deliberative process, it is argued, decision-making is seen as more valid and legitimate, even by those whose views might not have necessarily shaped the final decision (Dryzek 2002). These ideas can be traced through the concept of deliberative democracy as a specific means of engaging citizens in deliberative processes to reach consensus around policy issues. Today the idea of a deliberative system, in which multiple deliberative processes become increasingly interconnected, are expressed in proposals for an alternate democratic system (Dryzek 2002).

The third, and most directly relevant to this collection, is found in the field of public policy and governance. As noted above, the narrative of coproduction is strongly implicated in contemporary modes of collaborative or progressive governance, which over the last two three decades has offered an alternative to bureaucratic planning and market competition in the organisation and governance of public services. Although Elinor Ostrom is often credited with advancing the concept of coproduction, it noteworthy that in the mid-1960s the likes of Paul Davidoff (1965) talked of citizen 'advocacy' in urban planning and Sherry Anstein (1969) proposed a 'ladder' of citizens participation. The idea of citizen participation now finds expression in the narrative of collaborative governance, which like theories of deliberative democracy, talks of engaging stakeholders constructively in consensus-oriented decision-making processes (Ansell and Gash 2008; Emerson et al. 2012). Although the term co-production is not always explicitly used, it has increasingly come to characterise how researchers talk about the advances of New Public Governance (Osborne et al 2016; Pestoff et al. 2006). As noted earlier, similar idea can also be found in the fields of product development and marketing where product value is increasingly seen as co-created through interdependent exchange relationships (Vargo and Lusch 2008). This 'service dominant logic' approach has been applied to the context of public policy and management as an alternative to more established forms of New Public Management (Go Jeffries et al. 201Osborne et al. 2013).

What emerges from across these fields is an emphasis on the practical processes and challenges of governing co-production activities. The contemporary application of co-production methods typically focuses on, first, matters of 'design' or how to configure spaces and processes to enable effective coproduction; second, the identification and recruitment of relevant 'stakeholders' to participate in coproduction activities; third the methods of 'facilitation' to convene and enable coproduction; and fourth the management of power and status 'inequalities' amongst stakeholders (Emerson et al 2012; Fung 2007). By comparison there are relatively few critical commentaries that look 'inside' coproduction or question the assumptions of which coproduction is based. Indeed, Arnstein wryly observed that "citizen participation is like eating spinach: no one is against it in principle because it is good for you" (p.216).

Through the influence of these antecedent strands, we suggest the narrative of co-production has come to dominate contemporary social and public policy (Alford 2009; Osborne et al 2016; Pestoff et 
al. 2006); although its influence is arguably more prominent in some fields more than others, such as the health and care sectors, and there remain terminological differences between sectors, such as codesign and co-production. Nevertheless, co-production is now championed as much by policy-makers and professionals as by citizen groups or service users. Yet, we also suggest that critical questions need to be asked when those in power claim to be empowering those without power through forms of co-production. As noted in the literature of healthcare decision-making, for example, there is a risk of public involvement being tokenistic (Martin 2008) or for facilitation methods to privilege certain perspectives over others (Crompton et al. 2018). Indeed, even advocates of co-production have questioned the authenticity of observed decision-making activities and the legitimacy of result policy decisions (Fung 2015). Importantly, this line of thinking implicitly suggests there is some idealised model or template of 'authentic' co-production that, if designed and facilitated appropriately, will result in more representative and legitimate decisions. We suggest, however, that it is important to look beyond the grand narrative of co-production; to locate the articulation of this narrative in its specific historical and political context; and to look closer at how the situated practices of designing, facilitating or participating in co-production activities can both reflect and disrupt local meanings and relations of power. In other words, it calls for a decentring of coproduction.

This special issue derives from a workshop at the Center for British Studies at the University of California, Berkeley in April 2017. The papers seek to 'decenter' (Bevir 2013) co-production by focusing on the interplay between the elite narratives which circulate around co-production, the local traditions and resistances which interpret (or resist) the call to be co-productive, and the meaningful practices of governance on the ground. Co-production is seen to operate at different levels, incorporating policy-making, service organisation and delivery as well as research and innovation.

Conceptually, in looking at co-production, the papers draw out aspects of:

- Elite narratives: Analyses of the discourses and policies of political elites within the different levels and contexts of co-production, in so far as these have sought to promote novel modes of governance;

- Local traditions and resistance: Accounts of the diverse forms of knowledge with which civil servants, bureaucrats, mid-level public managers, and front-line workers have interpreted (and perhaps resisted) elite policy narratives and directives;

- Meaningful practices: Explorations of the myriad ways in which local actors have interpreted, and thus forged practices of governance on the ground. This requires the empirical study of governing in situ and a focus on the 'how' of governing.

Following a decentered theory of governance (Bevir 2013) enables an investigation into and explanation of 'the ways in which governance is created, sustained and modified by individuals acting on beliefs that are neither given by an objective self-interest nor by an institution, but rather arise from a process in which the individuals modify traditions in response to dilemmas' (Bevir 2013, p.50). In so doing, decentered theory 'avoids the suggestion that institutions fix the actions of the individuals acting within them [i.e. as a causal structure], rather than being products of their actions...[it centres] an analysis of change rooted in the beliefs and practices of situated agents...[and deploys] concepts of tradition and dilemma to explain how people come to hold widespread beliefs and perform intersubjective practices' (Bevir, 2013: 69). 
The articles in the special issue offer critical accounts of co-production in a range of policy domains, setting the elite narratives alongside local traditions and practices of resistance. While co-production in the design and delivery of health care has become an increasingly prominent policy narrative, there has been little acknowledgement of the intersubjective aspects of knowledge production and translation in prevention, nor of the challenges for street-level workers of implementing risk-based policies. In Gale et al's contribution to this special issue, they consider the extent to which co-production is possible within 'street-level' risk work - to develop a theoretical framework for analysing the potential for coproduction in the epidemiological clinic. They offer a decentred analysis of empirical data co-produced (using photo-voice methods) with community health workers to explore the diverse forms of knowledge with which street-level workers have interpreted elite policy directives (and to what extent they have resisted them).

Also taking a health focus, Crompton's paper examines service leaders' translation and implementation of a coproduction method, and the ways in which professional and patient stakeholders were engaged in deliberative activities, which were themselves informed by technical data on service costs and clinical outcomes. This case study brings to light the inherent tensions between elite and lay perspectives in design and implementation of co-production methodologies, and questions that idea that co-production necessarily leads to more accountable or just decisions. Clarke et al's article also has a health orientation. Drawing on four applied health research projects, the authors examine how coproduction occurs through routine and ritualistic patterns of everyday practices which have the potential to facilitate sustainable and inclusive research initiatives. Informed by interactional ritual change theory, they identify two types of interlinked inclusivity: relational, individuals routinely engaging together; and emotional, the feeling of being included.

Weaver's contribution to the special issue explores how the User Voice prison councils in England, have contributed to shifts in aspects of prison governance and practice. The User Voice model of prison councils represents an important example as to how different actors can co-create or co-produce alternative patterns of governance through innovations in democratic participation.

Richardson et al's paper explores the theories of change of more inclusive decentralised governance, focusing on local actors beyond elites. It documents how local actors chose to enact those theories of change in their own practices, using data from a single site case study of a co-produced action research project, situated in a northern city-region in the UK experimenting with devolved governance arrangements.

Using a case study of protests over the felling of street trees in Sheffield in the UK, Flinders and Wood argue that abolishing co-productive practices on the basis of austerity measures created fertile conditions for a political crisis. They argue that adding the concept of 'Co-production As Resistance' to researchers' toolkits can be useful for conceptualising co-production as a practice of asserting the normative ideal of co-production against messy institutional realities.

Moving away from the UK setting, Mcmullin's article explores the conceptualization of co-production in France, challenging the assumption of a universalist notion of co-production as co-design and codelivery. Mcmullin argues that differences in political traditions drive the framing of co-production in France, with a greater emphasis on political participation than on co-delivery, which is informed by the strength of the centralised state, lack of New Public Management reforms, and the notion of the social and solidarity economy. 
The final article in the special issue, by Allen et al, focuses on the co-production of research rather than services or policy. Funding for public service evaluation is increasingly subject to the satisfaction of two requirements: a participatory research design and adoption of validated outcome tools. Drawing on a co-produced research project, the authors identify the significant challenges faced by researchers who seek to reconcile these competing paradigms. The article suggests that more attention needs to be given to the implications of participatory research in challenging dominant norms of what is valid and reliable research.

Together, the articles in this collection raise important questions about coproduction as a mode of public governance, and a practice of policy decision-making and service delivery. Through taking a decentered approach (Bevir 2013) they show, in different ways, how the elite narrative of coproduction is manifest in different policy contexts, where it tends to offer an idealised view of better and more legitimate decision-making. But also, that in practice coproduction remains a problematic mode of governance, not simply because actors have different sources of power and influence (which is well recognised in the coproduction literature), but rather because the practices of policy actors continue to be influenced by local traditions and beliefs. Although the philosophy of coproduction might be explicitly concerned with bringing to light and reconciling differences in local beliefs, the articles in this collection show that divert local meanings persist not only around particular policy issues (healthcare, prisons, tree felling, research), but also about the meaning and utility of coproduction itself.

\section{References}

Alford, J. (2009). Engaging public sector clients: from service-delivery to co-production. London: Springer.

Ansell, C., \& Gash, A. (2008). Collaborative governance in theory and practice. Journal of public administration research and theory, 18(4), 543

Alford, J. (2014). The multiple facets of co-production: Building on the work of Elinor Ostrom. Public Management Review, 16(3), 299-316.

Arnstein, S. R. (1969). A ladder of citizen participation. Journal of the American Institute of planners, 35(4), 216-224.

Bate, P., \& Robert, G. (2006). Experience-based design: from redesigning the system around the patient to co-designing services with the patient. BMJ Quality \& Safety, 15(5), 307-310.

Brett, J., Staniszewska, S., Mockford, C., Herron-Marx, S., Hughes, J., Tysall, C., \& Suleman, R. (2014). Mapping the impact of patient and public involvement on health and social care research: a systematic review. Health Expectations, 17(5), 637-650.

Crompton, A., Waring, J., Roe, B., \& O’Connor, R. (2018). Are we all on the same page? A qualitative study of the facilitation challenges associated with the implementation of deliberative priority-setting. Public Management Review, 20(11), 1623-1642.

Department of Health (2012) Liberating the NHS: No Decision about me, without me, London: DoH. 
Davidoff, P. (1965). Advocacy and pluralism in planning. Journal of the American Institute of planners, 31(4), 331-338.

Dryzek, J. S. (2002). Deliberative democracy and beyond: Liberals, critics, contestations. Oxford: Oxford University.

Emerson, K., Nabatchi, T., \& Balogh, S. (2012). An integrative framework for collaborative governance. Journal of public administration research and theory, 22(1), 1-29.

Fung, A. (2007). Minipublics: Deliberative designs and their consequences. In Rosenberg, S. (ed.) Deliberation, participation and democracy (pp. 159-183). London: Palgrave.

Fung, A. (2015). Putting the public back into governance: The challenges of citizen participation and its future. Public Administration Review, 75(4), 513-522.

Gibbons, M. (Ed.). (1994). The new production of knowledge: The dynamics of science and research in contemporary societies. London: Sage.

Go Jeffries, J., Bishop, S. and Hibbert, S. (forthcoming) 'Service innovation through research integration: an empirical examination of the co-created value using telehealth services' Public Policy and Administration (forthcoming)

Habermas, J. (1984). The Theory of Communicative Action, Vol. 1, 'Reason and the Rationalization of Society'. Cambridge: Polity.

Martin, G. P. (2008). 'Ordinary people only': knowledge, representativeness, and the publics of public participation in healthcare. Sociology of health \& illness, 30(1), 35-54.

Mead, N., \& Bower, P. (2000). Patient-centredness: a conceptual framework and review of the empirical literature. Social science \& medicine, 51(7), 1087-1110.

Newman, J. (Ed.). (2005). Remaking governance: Peoples, politics and the public sphere. Policy Press.

Ostrom, E., Parks, R. B., \& Whitaker, G. P. (1978). Patterns of metropolitan policing. Cambridge, MA: Ballinger.

Ostrom, E. (2015). Governing the commons. Cambridge: Cambridge University Press.

Osborne, S. P., Radnor, Z., \& Nasi, G. (2013). A new theory for public service management? Toward a (public) service-dominant approach. The American Review of Public Administration, 43(2), 135-158.

Osborne, S. P., Radnor, Z., \& Strokosch, K. (2016). Co-production and the co-creation of value in public services: a suitable case for treatment?. Public Management Review, 18(5), 639-653.

Pestoff, V. (2006). Citizens and co-production of welfare services: Childcare in eight European countries. Public management review, 8(4), 503-519. 
Pestoff, V., Osborne, S. P., \& Brandsen, T. (2006). Patterns of co-production in public services: Some concluding thoughts. Public Management Review, 8(4), 591-595.

Vargo, S. L., \& Lusch, R. F. (2008). Service-dominant logic: continuing the evolution. Journal of the Academy of marketing Science, 36(1), 1-10.

Williamson, C. (2008). The patient movement as an emancipation movement. Health Expectations, 11(2), 102-112. 